\title{
Reciprocal Teaching Strategy as an Important Factor of Improving Reading Comprehension
}

\author{
Mohammad Reza Ahmadi (Corresponding author) \\ School of Educational Studies, Universiti Sains Malaysia \\ 11800, Penang, Malaysia \\ Tel: 60-17-527-1870Ｅ-mail: mr.ahmadi2720@gmail.com \\ Associate Prof. Dr. Hairul Nizam Ismail \\ School of Educational Studies, Universiti Sains Malaysia \\ 11800, Penang, Malaysia
}

Tel: 60-4-653-3760_E-mail: hairul@usm.my

Received: October 18, 2012 Accepted: October 30, 2012 Published: November 8, 2012

doi:10.5296/jse.v2i4.2584 URL: http://dx.doi.org/10.5296/jse.v2i4.2584

\begin{abstract}
Reading Comprehension is one of the most important skills, receives the special focus in foreign language teaching. Research has suggested that explicit reading strategies can be taught to students and enhancing their reading comprehension. The purpose of this study is to investigate the effects of reciprocal teaching on reading comprehension. Reciprocal teaching consists of four basic reading strategies: predicting, questioning, clarifying, and summarizing. Cognitive and meta-cognitive strategies are the reciprocal teaching strategies used to improve students' reading comprehension This article will discuss whether 'reciprocal teaching strategies' improve students reading comprehension or not. This lack of good reading comprehension skills is exacerbated by the central role of reading comprehension in higher education success. One solution to this problem of poor reading comprehension skills is the explicit teaching of reading comprehension strategies. This paper is going to define the key words, explain the models of reading process, follow reading process and reading strategies, discuss cognitive and meta-cognitive strategies and reading comprehension, elaborate reciprocal teaching and its theoretical framework, mention the related research on reciprocal teaching, and state relationship between reciprocal teaching and reading comprehension. The findings indicated that reciprocal teaching had a significantly positive effect on the English
\end{abstract}


reading comprehension and usage of the four main factors of reciprocal teaching strategies of EFL students.

Keywords: Reciprocal teaching, Reading comprehension, Cognitive and meta-cognitive strategies. 


\section{Introduction}

Along with the improvement of international communication activities, and interests in industrial science and knowledge, the learning of English in the world is becoming more important. International activities in the world such as book fairs, trade exhibitions and conferences which held annually in the world indicated the importance of English as to be mastered in the world (Maleki \& Zangani, 2007). According to Chang (2006), English language teaching is one of the most important factors of international communication activities. It is ideal to train students to be able to use language in various conditions: reading, writing, speaking and listening to facilitate their international communication. However, in foreign language learning, teaching method is most important factor for the learners to be motivated in their activities (Grabe \& Stoller, 2002).

Reading comprehension is known as an interactive mental process between a reader's linguistic knowledge, knowledge of the world, and knowledge about a given topic (Rahmani \& Sadeghi, 2011). One solution to this problem of poor reading comprehension skills is the explicit teaching of reading comprehension strategies to both undergraduate and graduate students. Hodge, Palmer, and Scott (1992) determined that college-aged students who were ineffective readers often did not monitor the comprehension of their reading, and rarely instigated any strategies to adjust to deficiencies in reading comprehension. In addition, Meyer, Young, and Bartlett (1989) demonstrated that explicit instruction in reading comprehension strategies is an effective means for improving reading comprehension in adults. Unfortunately, explicit instruction in reading comprehension is rarely taught at the higher education level (Wilson, 1988; Pressley, Woloshyn, Lysynchuk, Martin, Wood, \& Willoughby, 1990).

Second/foreign language researchers have stressed the importance of training language learners to be strategic readers. Paris et al., (1983) highlight that learning to be a strategic reader can promote reading comprehension and "failure to be strategic in reading may result from either developmental inability or poor learning” (p. 293). Palincsar and Brown (1984) suggest that strategic reading helps students, especially low-achieving learners, avoid comprehension failure and enhance their retention of the text. Similarly, Koda (2004) points out that strategic reading can not only compensate for learners' comprehension deficiency but also develop their critical thinking.

Reciprocal teaching strategy explored by Palincsar and Brown (1984) is one of the most effective methods for teaching a foreign language and facilitates learning in different areas world Pressley (2002). Oczkus (2004) advocated that reciprocal teaching assists learners in a different teaching and learning situations and it is an explicit teaching by the instructor in the learners' use of the strategies. Reciprocal teaching strategy improves learners' reading comprehension, facilitates foreign language learning and helps them to improve the ability to work co-operatively with their classmates. Hasan (1994) explained that reciprocal teaching strategy does not only facilitate reading comprehension in an EFL context; it also gives learners the opportunity to use English to serve many of the language functions and notions that are typical in communicative approach. 
Pressley (2006) contends that language learners should be taught strategic reading through explicit instruction. Janzen and Stoller (1998) maintain that strategic reading instruction is rewarding to both second language learners and their teachers. They argue that it cultivates learners' autonomy and self-awareness of the meaning constructing process and it also prepares pre-university students for academic reading performance. They also indicate that reading strategy instruction provides an efficient method for teachers to motivate students' participation in their learning and teach them how to read effectively.

\section{Reciprocal Teaching Strategy}

Stricklin (2011) defined reciprocal teaching as an instructional strategy that directly teaches students to apply meta-cognitive thinking as they make meaning from a text. It is a process of reading comprehension as an interactive one, in which readers interact with the text as their prior experience is activated. Moreover, readers construct meaning from the text by relying on prior experience to parallel, contrast or affirm what the author suggested in the text. Reciprocal teaching strategy allows a teacher to model and give the students enough practice on those four main strategies (predicting, questioning, clarifying and summarizing) to construct the meaning of a text in a social setting (Stricklin, 2011).

Reciprocal teaching strategy is an instruction that directly teaches learners to apply meta-cognitive thinking as they recognize meaning from a context (Rosenshine and Meister, 1994). Carter (1997) advocated that, reciprocal teaching strategy is the interactive process of reading, where learners interact with the passage as their background knowledge is activated. Using background knowledge as a way, learners learn new information, key points and main ideas. So, learners create meaning from the text by relying on background knowledge, contrast or affirm what the author suggests. The content would be meaningless, if good learners do not follow this construction on the passage. And also learning does not take place without meaning construction.

Lysynchuck et al. (1990) stated that reciprocal teaching strategy is a model to promote reading comprehension abilities in learners with basic decoding process, which can also be considered as a strategy that facilitates learners to promote their reading comprehension through explicit teaching of reading comprehension strategy. In other words, it is a method that improves cognitive and meta-cognitive processes for the learners which help them to use the strategies of planning, controlling and evaluating at their own reading method. Reciprocal teaching is a dialogue model among the learners themselves or between the learners and the instructor. This model might exchange the roles between the instructor and the students, and it puts the sense of responsibility on the learners for their roles in the process, as well as allowing learners to support each other continuously (Hacker \& Tenent, 2002).

Hacker and Tenent (2002) elaborated reciprocal teaching as a scaffold dialogue model based on social interaction and reading comprehension learning strategy. This instructional model helps teachers to model main strategies to construct the meaning of a passage in a social interaction and give learners enough practice on these four reciprocal teaching strategies. During the process, learners evaluate and monitor their own thinking through reading, and their comprehension will be developed. This strategy improves a learner's reading 
comprehension in order to step further in reaching the goal of reciprocal teaching, to be an independent reader. In other words, reciprocal teaching strategy can be described as a collaborative work among students themselves and students with teacher to help students who have problems recognizing the text (Palincsar \& Brown, 1984).

\subsection{Component of Reciprocal Teaching Strategy}

According to Brown and Campione (1992), components of reciprocal teaching strategy are namely predicting, questioning, clarifying and summarizing. These components are described in the following subsections.

\subsubsection{Predicting}

In this prediction stage, students will predict the message in the text content while being aware whether their guessing are correct or wrong (Palincsar, Brown \& Martin, 1987; Taylor \& Frye, 1992). Prediction stage is a chance for learners before reading the passage to create important imagination of passage's title. As a conclusion, predicting includes joining the reader's background knowledge, new information from the passage, and the passage's construction to make assumptions related to the direction of the passage and the author's massage in writing. Doolittle et al. (2006) explained that students make predictions of the text based on their related background knowledge. In this process, students describe a context and guess the content of the next paragraph or passage. Through the information in a context, students will predict which information may be in the next pages.

\subsubsection{Questioning}

In this section, the instructors will ask their students to find the most important information in the passage. Students can ask a lot of questions that are related to their passage and show their knowledge about the context. For example, the teacher might ask his/her students about the main point of a paragraph. By generating questioning activities, students can find information, themes, and important points of the passage that are needed to be more focused; the main points and recommendation will be used for questioning activities by the students. Accordingly, questioning would help to reach the goal quicker (Palincsar, Brown, \& Martin, 1987; Taylor \& Frye, 1992).

\subsubsection{Clarifying}

In this stage, clarification of difficult or unfamiliar aspects of a passage, which may include unfamiliar or unclear idioms, vocabulary, references, or unknown sentences, will take place (Doolittle et al., 2006). Clarifying is a meta-cognitive strategy, where readers may re-read the passage in order to clarify any unclear information.

Some procedures, such as using dictionary and thesaurus, or even asking for help from the instructors are to be followed by the readers in order to find the obstacles in the text such as new expressions, idioms or vocabularies in order to improve the understanding. In other words, this stage includes the explanation and definition of unknown, complex, or unclear aspects of a passage (Palincsar, Brown, \& Martin, 1987; Taylor \& Frye, 1992). 


\subsubsection{Summarizing}

Summarizing is the action of explaining the most significant data, issue, and opinion within a passage. This strategy allows the reader to recognize, detect, correlate and arrange the main ideas in the passages. To rewrite the passage using their own words while maintaining the basic points might also improve the students' capabilities to concentrate on significant parts of the text (Palincsar, Brown, \& Martin, 1987; Frye \&Taylor, 1992). They agreed that, instructors might enhance the students' understanding by asking questions related to the main point of the passage.

In other words, summarizing helps reader to accomplish the assignment of distinguishing significant information in the content (Palincsar \& Brown, 1984). This stage is helpful for the students to improve their comprehension because it emphasizes on passages, paragraphs or sentences and also makes words understandable in a special context (Doolittle et al., 2006).

\subsection{History of Reciprocal Teaching}

Reciprocal teaching was designed as an instructional approach to improve students' reading comprehension at all levels and in all subject areas (Palincsar \& Brown, 1984). Reciprocal teaching was introduced to help learners improve the ability to construct meaning from passage and control their reading comprehension. Learners study a set of cognitive strategies, modeled by the instructor and practiced by learners in collaborative work, that are used to structure discussions of the passage (Florida Online Reading Professional Development, 2005a; Foster \& Rotoloni, 2005; Promising Practices Network, 2005).

Students with strategy are aware of their own reading a text and have the ability to use self-correction in an attempt to figure out the passage (Florida Online Reading Professional Development, 2005b). Biemiller and Meichenbaum (1992) elaborated that the differences between the highest- and lowest learning achievement in reading comprehension is in the degree to which students become self-monitoring of their own learning. Esisential components of reciprocal teaching strategy, such as self-evaluation, goals, plans, requesting for help, and using monitoring strategies are helpful in improving reading comprehension, (Educational Research Service, 2003; Hashey \& Connors, 2003; Oczkus, 2003).

\subsection{Goals of Reciprocal Teaching Strategy}

McLaughlin \& Allen (2002) and Pearson, et al. (1992) elaborated that reciprocal teaching strategy was designed by Palincsar and Brown in 1984 with different goals and facilitates students reading comprehension in different grade levels. The goals of reciprocal teaching strategy are as follows:

A. To enhance learners' reading comprehension through four reciprocal teaching strategies (making prediction, generating questioning, clarifying and summarizing).

B. To frame the four reciprocal teaching strategies by modeling, helping, guiding, and providing the strategies while reading.

C. To direct learners to become meta-cognitive and reflective in using the four strategies; 


\section{$\triangle$ Macrothink}

D. To assist learners evaluate their reading comprehension through reciprocal teaching strategy.

E. To utilize the classroom environment of learning to increase and frame reading comprehension.

F. To empower instruction in a different classroom environment, help students in reading comprehension.

G. To be part of the bigger framework of reading comprehension strategies that provides reviewing, generating questioning, making predictions, evaluating and monitoring.

\section{Reading comprehension}

Reading comprehension is a combination of the reader's cognitive and meta-cognitive processes, which a reader has to make inferences on the context of a text or at the end of a story by using information from various sources: the title, the illustrations, or generally from the previous paragraphs. The reading comprehension processes occur when the reader understands the information in a text and meaningfully interprets it appropriately (Blair-Larsen \& Vallance, 2004).

The conclusion of recognition among readers and the context is called reading comprehension (Eskey, 2005). Many of the strategies instruction occurred as a result of the earlier proposal from Rosenblatt (1978), that reading is a transaction among the text and reader. It is believed that readers establish and construct their own meanings and in the context of small-groups, readers can share those understandings. Decoding and the ability to recognize words has been shown to be one of the most important features of the beginning stages of reading and reading development (Adams, 1990); while comprehension relies on both word recognition skills and higher order thinking skills.

Duke (2003) proposed that reading comprehension is a process at once to construct and recognize the massage of written language; he stated furthermore, that readers go through context; evaluate meaning and, finally arrive at a self-selected location. Accordingly, Van Den Broek and Kremer (2000) stated that readers in reading comprehension create an image and its definition toward the comprehension process in their mental. On the other hand, Martin, Chang and Gould (2008) define reading as one of the most important factor in language learning. Their idea was supported by the fact that many researchers said reading will help and improve language learning. Reading also helps learners to improve themselves in various situations such as vocabulary knowledge, writing skills, and spelling (Harmer, 2007).

Reading is a complex process which includes the ability to read real words in isolation or in context with comprehension (Reid \& Lienemann, 2006). Students need to be able to comprehend text in many different content areas; they need the ability to construct meaning from written language by manipulating, constructing, and translating text. Accordingly, Erfani et al. (2010) and Farhady (2005) agreed that in Iranian universities context, reading 
comprehension is the most important skill to be acquired by the students, and it is the most effective motivation factor for them to be successful in their study.

\subsection{Types of Reading}

In general, reading activity can be divided into two types namely Extensive and Intensive Reading. The following subsections discuss about the two types in more details.

\subsubsection{Extensive Reading}

Hedge (2003) emphasized that extensive reading is related to scanniing and skimming activities and others associate it to quantity of material. It is defined as reading in quantity and in order to gain a general understanding of what is read, interactive-activities, obtaining the gist to facilitate reading comprehension. Furthermore, Hafiz and Tudor (1989), Grabe and Stoller (2002) added that extensive reading refers to a large amounts of reading in second language texts within their linguistic competence with the purpose of learning to read. Furthermore, it is considered a pedagogically efficient method to teach reading by having students read many materials in their linguistic process.

On the other hand, Richards and Rodgers (2003) explained extensive reading as reading book after book where the readers need to focus on the meaning of the text, while it gives them a general sense of the passage. Field (1985) and Munby (1978) argued that extensive reading is a rapid and effective method of reading a passage for a general meaning. All interested and pleasure reading is defined as extensive reading.

\subsubsection{Intensive Reading}

Intensive reading is defined as reading in details to understand the meaning of the words and the definition of context (Day \& Bamford, 1998). Intensive readers focus on grammatical points, vocabulary key words, details in structure, with the aims of understanding literal meaning and implications. They explained that intensive reading is a close study of contexts, sentences or paragraphs and it will activate the shift from first language to foreign language; hence it improves the learners' vocabulary knowledge and reading comprehension.

In Intensive reading, readers usually read a text to understand the writer's message(s). Hedge (2003) pictured intensive reading as reading carefully and slowly for detailed understanding. Hafiz and Tudor (1989) supported the definition by stating that intensive reading is generally at a slower speed and requires a higher degree of understanding to develop and refine word study skills, enlarge passive vocabulary, reinforce skills related to sentence structure, increase active vocabulary, distinguish among thesis, fact, supportive and non-supportive details, provide socio-cultural insights.

\subsection{Models of Reading}

There are three models for reading: the bottom-up model which emphasizes on the contexts, the top-down model which emphasizes on the readers, and the interactive model which emphasizes that the reading process is guided by an interaction between the text information 
and the reader's previous knowledge (Tolstefl, 2007). The following subsections discuss about each of the model in more details.

\subsubsection{The Top-down Model}

In Top-Down Model, background knowledge activities, prediction, main idea, contextual guessing, scanning and skimming are provided; the prospects and previous information help readers to recognize meaning in their reading process (Eskey, 2005). In this model, readers begin to read a passage and utilizing their previously learned information to get new experiences and knowledge (Aebersold \& Field, 1997).

In top-down model, readers use their background knowledge to predict meaning (Goodman, 1976). Accordingly, active readers translate the message of writers in their own language in a meaningful form (Smith, 2004). Therefore, good readers do not need to read all of the vocabulary in a context, but they will recognize the message of the context by getting some important of words and sentence (Cohen, 1990). In other words, the model of top-down emphasizes on reading proficiency and focuses on predicting the message by using the readers' prior knowledge related to the context.

\subsubsection{The Bottom-up Model}

Bottom-up Model emphasizes on surface meaning, using a dictionary for translating new vocabularies for facilitating reading comprehension (Stanovich, 1980; Chastain, 1988; Dubin \& Bycina, 1991; Carrell, 1991). This model is normally used at the earlier level of study (Hayashi, 1999).

Reading process in the bottom-up model starts with the decoding of the smallest elements of linguistic especially phonemes and words, continued with creating meaning from the larger elements (Carrell, 1989). Gough (1972) added that bottom-up model focuses on the print itself, whereas reading is the starting point to grasp understanding in words description, letters information, linguistic elements and sentences before recognizing the meaning the whole text.

The aforementioned descriptions are in line with the statement of VanDuzer (1999), that whole process of defining content through decoding of new words is called bottom-up reading process. Grabe and Stoller (2002) supported the idea by stating that bottom-up model is a mechanical model, where readers translate the content mentally from smallest units; obviously, readers' previous information may not be considered too much in the process.

\subsubsection{The Interactive model}

Interactive model is the combination of the two aforementioned models (bottom-up and top-down).This model is based on information from different parts such as semantic information, lexical, schemata, orthographic and syntactic (Stanovich, ,1980). Interactive model covers what top-down or bottom-up model uncovered in the whole process of reading (Rumelhart, 1977). 
It is not a coincidence that Stanovich (1980) also explained that one of the efficient method based on interaction model is called reciprocal teaching method, because reciprocal teaching model emphasizes on the relationship between the text and the readers. Anderson (1991) added that interactive model is the most effective approach to teach the first and second language speakers to read. Accordingly, Grabe (1991) reported that interactive model is efficient to bridge between students with higher-level and lower-level of reading comprehension proficiency.

Stanovich (1980) mentioned that top-down and bottom-up models might assist each other in the process of reading. It was reported that because poor readers have limited capability of bottom-up approach, they use top-down model more than proficient readers (Eskey, 2005; Stanovich, 1980).

\section{Cognitive and meta-cognitive strategies and reading comprehension}

Cognitive strategies, or learning to think strategically, assist the students to remove barriers they encounter while they are reading and it is a kind of volition which planed to improve learning in different conditions (Alexander, Graham, \& Harris, 1998; Dole, Nokes, \& Drits, 2009).

Cognitive strategies are taught to the learners through discussion and support to enhance reading comprehension, and improve students' motivation in their learning (Palincsar, David, \& Brown, 1989). Reciprocal teaching is one of the effective strategies that assist learners' learning through cognitive strategies by suitable instructions (Rosenshine \& Meister, 1994).

Flavell (1979) elaborated that individual information about cognitive process and strategies is called meta-cognitive strategy. Livingston (1997) stated that thinking about thinking is meta-cognitive interpretation, and that the concept of meta-cognition has been enthusiastically accepted, especially with regard to reading, for three reasons as follows: (1) It emphasizes the activities of reading in strategic. (2) It emphasizes cognition of the reading process. Asking questions from young learners indicated that they do not know about the reading strategy. (3) Meta-cognition has become significant and acceptable element in investigation on reading.

\subsection{Theories Related to Reciprocal Teaching}

The reciprocal teaching strategies are methods basically improved by Palincsar and Ann Brown in1980s. It is considered as the most vital instruction for reading comprehension strategies; which consists of four strategies: predicting, generating questions, clarifying, and summarizing. Furthermore, it assists learners reading comprehension ability. The aim of this strategy is to improve cooperation between students and teacher and students among themselves. This cooperation will enhance learners reading comprehension, improve their manipulating ability, checking their ability of reading comprehension, and enhance their motivation (Borkowski et al., 1990; Allen, 2003).

Theories of reciprocal teaching are fundamentally based on three branches which included: the zone of proximal improvement, proleptic exercising, and skilled framework (Brown \& 
Palincsar, 1984). The Zone of proximal improvement refers to a student's capable skill to study with assistance from teacher or a capacity of partner. This theory is related to the theory of Vygotsky (1978) who explained that students have two actions of thoughtful improvement: a real improvement action and a capable improvement action. The real improvement action refers to the thoughtful action in which teenagers can fix difficulties without any helping, while the capable improvement action indicates to the thoughtful action in which students want assistance from a skill person with assistance from the teacher or a capacity of co-worker. Nature of proximal improvement is the length among the real improvement and the capable improvement. Students will be urged from the real improvement action to the capable improvement or study over their real improvement level with clear framework through human activity till they internalize the method (Rosenshine \& Meister, 1994).

Proleptic exercising is another branch which creates theoretical ground for reciprocal teaching. It refers to a program which established while novitiate teaching in which a teacher model a student till he or she become ready to do the assignment individually (Palincsar \& Brown, 1984). Proleptic teaching has a vital element that removes accountability from instructor to learners; in order to solve a problem instructor elaborates and provides methods for the students. Subsequentially, when the teacher responsibility is decreased he/she will remove the action of problem solving to the learners (Rogoff \& Garner, 1984).

Greenfield (1984) explained that framework exercising is suitable for the students' present studying. In order to improve the students' ability further, more support can be offered to the learners. In the case where learners do not need much assistance, the instructor will play his/her role as a guide.

Framework inflicts and enhances autonomous reading comprehension ability, as these elements were included the previous hypotheses in reciprocal teaching by Adunyarittigun \& Grant (2005). Their hypotheses are as follows: (1) The instructor helps the learners to suit themselves in using these four key models. (2) The instructor plays his/her role as a specialist of reciprocal teaching strategies to help the learners. (3) The learners are assisted by more skilled partners as the instructor does not help them any longer, in order to improve their autonomous reading comprehension ability.

Reciprocal teaching strategy consists of four important key factors for reading comprehension for learners to recognize the passage/content more than other strategies. One of the contributions of reciprocal teaching to the learners of reading comprehension is that it prepares them to read autonomously, whilst at the early stage, it allows them to communicate among themselves and instructors in order to improve their skills.

\section{Relationship between Reading Comprehension and Reciprocal Teaching Strategy}

Reading comprehension can be improved by reciprocal teaching strategy and by making reading relevant to learners' lives and attitudes, it will create what learners know and believe and by being mindful of their purposes and hopes for their futures (Guthrie \& Wigfield, 2000). Instructors will provide reading environment that are suitable, interesting and appropriate to learners' reading capabilities to assist in improving their comprehension. 
Reading comprehension is improved by reciprocal teaching which activates background knowledge in ways of pre-reading, while reading and after reading, in instructing students to get information and in monitoring their reading during their reading time (Guthrie \& Wigfield, 2000).

Hacker and Tenent (2002) explained that several instructors for enhancing learners' proficiency, they changed the old models of reading comprehension and used reciprocal teaching strategy in order to help learners reading comprehension. They stated that, investigators emphasized that reciprocal teaching strategies not only assisted learners in their reading comprehension but also helped students arrange the conceptual structure of learners' information and improve their' high thinking proficiency and their ability to write.

It is also indicated that reciprocal teaching strategy is more efficient to improve reading comprehension with low capability Oczkus (2004). This strategy consists of explicit teaching by the instructor in the learners' use of the reciprocal teaching model (prediction, generating questioning, clarifying and summarization) to improve their understanding. Accordingly, Oczkus (2004) explained that reciprocal teaching strategy facilitates learning and helps students to increase their vocabulary knowledge in their reading comprehension in different kinds of learning situations.

Reciprocal teaching showed that instructors want to provide this strategy to improve learners' higher proficiency (Plinscar \& Brown, 1989; Carter, 1997; Greenway, 2002; Allen, 2003; Todd \& Tracey, 2006). Reciprocal teaching is a assistance strategy for learners with special needs (Bruce \& Chan, 1991; Dao, 1991; Palincsar \& Klenk, 1992; Klingner \& Vanghn, 1996; Lederer, 2000). Marzano (2001) argued that reciprocal teaching helps cooperation, responsibility and leadership; it enhances learners' reading comprehension, improves their social cooperation and decreases undesirable behaviors in the classroom. Palincsar and Brown (1984) sated that the goals of reciprocal teaching are to improve the learners' ability to create meaning from content and facilitate the checking of their way to comprehension. These strategies of predicting, questioning, clarifying, and summarizing improve reading comprehension (Dole et al., 1991).

Baker and Brown (1984) and Palincsar and Brown (1985) explained that these basic strategies were on the following criteria: A) the successful learners use these strategies; B) these strategies help both comprehension checking and comprehension fostering; C) each strategy is used while there is a problem in reading a content; D) these strategies are known as meta-cognitive models. For making English language learning successful and effective, instructors must teach EFL learners with these strategies. As ESL/EFL investigators explained teaching productive reading models to ESL/EFL learners to motivate reading and help reading comprehension (Anderson, 2003; Chern, 1993; Eskey, 2002; Farrell, 2001; Grabe, 2004), While researchers in the U. S. has advocated for teaching productive reading strategies to ESL learners to motivate and facilitate reading (Anderson, 2001, 2003; Eskey, 2002; Farrell, 2001; Grabe, 2004), English language teachers must know that it is necessary to foster motivation and positive attitude towards reading comprehension between learners and also should incorporate reading strategies instruction in English environment (Chu, 2000; 
Yang, 2000; You, 2004). Reciprocal teaching strategies instruction cannot be avoided and numerous foreign language teaching studies have explained that struggle learners' reading comprehension developed after receiving explicit instruction in meta-cognition (Palincsar \& Brown, 1984; Baker, 2002; Cohen, 2003; Grabe, 2004; Duffy, 2005).

Roehler and Duffy (1984) stressed the crucial role of teacher modeling in facilitating learners' reading comprehension. In this approach, teachers explicitly provide declarative knowledge (what the strategies are), conditional knowledge (when to use them) and procedural knowledge (how to use them). Scaffolding in instruction and teachers' feedback is reduced when students become more independent in the application of reading strategies. A series of Duffy and his colleagues' experimental studies suggest that less able students who receive direct explanation of comprehension strategies which characterizes direct explanation, teacher modeling and guided practice of reading strategies show positive improvement in conceptual understanding and reading achievement (Roehler \& Duffy,1984; Pearson \& Dole, 1987; Duffy et al., 1988).

It can be concluded that, there is a strong relationship between reading comprehension and reciprocal teaching strategy which providing vital reading strategy instruction that emphasizes on meta-cognitive awareness. Its purpose is to enhance readers' reading comprehension proficiency and to help their becoming independent readers. It suggests three models: scaffolding and direct instruction, practice of the four main strategies, and social interaction which has been influenced by Palincsar and Brown's reciprocal teaching theory Chen (2005).

\section{Conclusion}

According to the findings of this study, it can be concluded that reciprocal teaching strategy effects strongly on reading comprehension and students' meta-cognitive reading strategies. Based on the results on this paper, reciprocal teaching improves students' reading proficiency of both the proficient and less proficient readers. Readers use sub-sections of reciprocal teaching strategies (predicting, questioning, clarifying and summarizing) and know how to use (when, why and how) each of the four main strategies. Students learn to make prediction, to make question, to find the main point of a text, to find the meaning of unclear words, and to summarize the text by their own sentences. The four main strategies of reciprocal teaching facilitate readers overcome problems while reading texts, as they plan and monitor their reading; evaluate reading and comprehension and also their outcome. So, as mentioned in previous sentences, it is obvious that reciprocal teaching is one of the main important strategy and instruction that helps students' reading comprehension. Reciprocal teaching strategy is one of the key factors that enhance students' meta-cognitive awareness on reading comprehension. It helps readers to think and plan about their reading process, improve activities, monitor and evaluate their reading while reading a text in order to understand the message/messages of the author. Readers by using reciprocal teaching strategies would be able to become independent readers, and could be reached the goal of teaching reading foe EFL students. In conclusion, it is known that reciprocal teaching strategies require sufficient meta-cognitive reading instruction since those incorporate scaffolding and explicit teaching 
of strategies which provide an environment that create productive information processing and reading comprehension. To sum up, reciprocal teaching is one of the main pedagogical implications for readers, teachers and educators in an EFL reading text which improves the readers' meta-cognitive awareness and reading comprehension. Therefore, these results in practice can be applies in EFL reading comprehension classrooms as are shown in follows:

A. Teachers teach students to use the four key factors of reciprocal teaching to enhance their reading comprehension through four reciprocal teaching strategies (making prediction, generating questioning, clarifying and summarizing). The teachers could help the students to understand the process and procedure of reciprocal teaching by checking their understanding in their native language in order to make sure that they understand and know these process and procedure.

B. Teachers frame the four reciprocal teaching strategies by modeling, helping, guiding, and providing the strategies while reading. The teachers model explicitly and step by step the process and the use of the meta-cognitive strategies. The students have to know what the four key strategies are and when, why, and how to use each of them.

C. Teachers direct learners to become meta-cognitive and reflective in using the four strategies. They need to improve students' responsibility and their role changes to facilitators. They should be flexible and attentive to help each student. The teachers should help students if the learners have any problem while reading and assist learners evaluate their reading comprehension through reciprocal teaching strategy.

D. To utilize the classroom environment of learning to increase and frame reading comprehension. To empower instruction in a different classroom environment, help students in reading comprehension. To help students while they are working in cooperative groups, the teachers should circulate around the room and listen to the students' interactions. If the learners need help, they should be taught in their groups using appropriate mini-lessons. Four main strategies of reciprocal teaching should be part of the bigger framework of reading comprehension strategies that provides reviewing, generating questioning, making predictions, evaluating and monitoring. Reciprocal teaching is one of the successful meta-cognitive reading strategy instructions for EFL students. Thus, reciprocal teaching should be taken into consideration in order to adapt its implementation in the English reading classroom.

\section{Acknowledgements}

The researchers would like to thank Mr Abbas Pourhossein Gilakjani, Mrs sareh shaker haghighi for their extensive and insightful discussions.

\section{References}

Adams, M. J. (1990). Beginning to read: Thinking and learning about print. Cambridge, m A: MIT Press.

Adunyarittigun, D., \& Grant, R. (2005). Empowering students through reciprocal teaching. Thai TESOL BULLETIN, 18(1), 1-13. 
Aebersold, J. A., \& Field, M. L. (1997). From reader to reading teacher. Cambridge: Cambridge University Press.

Alexander, P. A., Graham, S., \& Harris, K. R. (1998). A perspective on strategy research: Progress and prospects. Educational Psychology Review, 10(2), 129-154. http://dx.doi.org/10.1023/A:1022185502996

Allen, S. (2003). An analytic comparison of three models of reading strategy instruction. IRAL, 41, 319-338. http://dx.doi.org/10.1515/iral.2003.015

Anderson, N. J. (1991). Individual differences in strategy use in second language reading and testing. Modern Language Journal, 460-472. http://dx.doi.org/10.1111/j.1540-4781.1991.tb05384.x

Anderson, N. J. (2003). Meta-cognitive reading strategies increase L2 performance. Modern Language Journal, 27(7).

Baker, L. (2002). Meta-cognition in comprehension instruction. In C. C. Block \& M, Pressley. (Eds.), Comprehension Instruction: Research based best practices, 77-95, New York: Guilford.

Biemiller, A., \& Meichenbaum, D. (1992). The nature and nurture of the self-directed learner. Educational Leadership (October 1992), 75-80.

Blair-Larsen, S. M., \& Vallance, K. M. (2004). Comprehension instruction in a balanced reading classroom. In S.M. Blair-Larsen \& K. A. Williams (Eds.), the balanced reading program: Helping all students achieve success (pp.37-52). Newark, NJ: International Reading Association.

Borokowski, J. G., Carr, M., Rellinger, L., \& Pressley, M. (1990). Self regulated cognition: Interdependence of meta-cognition, attributions and self esteem. In B.J. Jones., \& L. Idol (Eds.). Dimensions of thinking and cognitive instruction (pp. 53- 92). Hillsdale, NJ: Erlbaum.

Brown, A., \& Campione, J. (1992). Students as researchers and teachers, in J. W. Keefe \& H. J. Walberg (Eds.), Teaching for thinking (pp. 49-57)

Bruce, M., \& Chan, L. (1991). Reciprocal teaching and trans-environmental programming: A program to facilitate the reading comprehension of students with reading difficulties. Emedial and Special Education, 12(5), 44-54. http://dx.doi.org/10.1177/074193259101200507

Carrell, P. L. (1989). Metacognitive awareness and second language reading. Modern Language Journal, 73, 120-133. http://dx.doi.org/10.1111/j.1540-4781.1989.tb02534.x

Carrell, P. L. (1991). Second language reading: Reading ability or language proficiency? Applied Linguistics, 12(2), 159-179

Carter, C. (1997). Why reciprocal teaching? Educational Leadership, 54(6), 64.

Chang, J. (2006). Globalization and English in Chinese higher education. World Englishes. 25(3), 513-525. http://dx.doi.org/10.1111/j.1467-971X.2006.00484.x 
Chastain, K. (1988). Developing second language skills: Theory and Practice. Harcourt BracJovanish, Inc. Florida: U.S.A.

Chen, J. C. (2005). Explicit instruction of reading strategies at senior high school in Taiwan. Unpublished MA dissertation, National Kaohsiung Normal University. Kaohsiung, Taiwan.

Chern, C. L. (1993). Chinese students' word-solving strategies in reading in English in T. Huckin,M. Haynes, \& C.Coady (Eds.), Second language reading and vocabulary learning(pp.67-85). Norwood, NJ: Ablex.

Chu, H. C. (2000). Orienting EFL readers toward global strategy use. Selected Papers from the Ninth International Symposium on English Teaching (pp. 274-283). Taipei: crane.

Cohen, A. D. (1990). Strategies in second language learning: Insight from research. In R. Phillipson., E., Kellerman, L., Selinker, M.S., Smith, and M. Swain (eds,): Foreign/Second Language Pedagogy Research. Cleve: Multilingual matters. http://dx.doi.org/10.1515/iral.2003.013

Cohen, A. D. (2003). The learner's side of foreign language learning: Where do style, strategies, and tasks meet? International Review of Applied Linguistics, 41, 279-291.

Dao, M. (1991). Designing assessment procedures for educationally at risk Southeast Asian -American students. Journal of Learning Disabilities, 24(10), 594-601. http://dx.doi.org/10.1177/002221949102401002

Day, R. R., \& Bamford, J. (1998). Extensive reading in the second language classroom. Cambridge University Press.

Dole, J. A., Nokes, J. D., \& Drits, D. (2009). Cognitive strategy instruction. In S. E. Jam, \& G. G. Duffy (Eds.), Handbook of research on reading comprehension (pp. 347- 372). New York: Routledge.

Doolittle, P. E., Hicks, D., Triplett, C. F., Nichols,W. D., \& Young, C. A. (2006). Reciprocal teaching for reading comprehension in higher education: A strategy for fostering the deeper understanding of texts. International Journal of Teaching and Learning in Higher Education. 17(2), 106-118.

Dubin, F., \& Bycina, D. (1991). Academic reading and the EFL/ESL teacher. In M. Celce-Murcia(ed). Teaching English as a second or foreign language. Massachusetts: Heinle., \& Heinle Publishers.

Duffy, G. (2005). Meta-cognition and the development of reading teachersi. In C. Block, S. K. Kinnucan-Welsch, \& K. Bauserman (Eds.) (pp. 299-314). Metacognition and literacy learning. Mahwah, NJ: Erlbaum.

Duffy, G. G., Roehler, L. R., \& Herrmann, G. (1988). Modelling mental processes helps poor readers become strategic readers. Reading Teacher, 41, 762-767.

Duke, N. (2003). Comprehension instruction for informational text. Presentation at the annual meeting of the Michigan Reading Association, Grand Rapids, MI. 


\section{Macrothink Institute ${ }^{\mathrm{TM}}$}

Educational Research Service. (2003). Helping students develop the skills of highly effective learners. ERS focus on. Arlington, VA: Educational Research Service.

Erfani, S. M., Iranmehr, A., \& Davari, H. (2010). Using task-based instruction as an alternative approach in ESP materials development in Iranian academic context. Proceedings of the first conference on new perspectives in ELT, linguistics and literature, Sanandaj: Iran

Eskey, D. E. (2005). Reading in a second language. In E. Hinkel (Ed.), and book on Second Language Learning and Teaching (pp. 563-579). Mahwah,NJ: Erlbaum

Eskey, D. E. (2002). Reading and the teaching of L2 reading. TESOL Journal, 11, 1, pp.5- 9.

Farhady, H., (2005). Reflections on and directions for ESP materials development in SAMT, in Kiani \& Khayamdar (eds.) Proceedings of the First National ESP/EAP Conference, 3 , Tehran, SAMT Publication.

Farrell, T. S. C. (2001). Teaching reading strategies: “It takes time!” Reading in a Foreign Language, 13 (2), 631-646.

Field, M. L. (1985). A psycholinguistic model of the Chinese ESL reader. In P. Larson, E. L. Judd, \& D. S. Messerschmitt (Eds.), On TESOL'84: A brave new world for TESOL (pp. 173-183). Washington, DC: TESOL.

Flavell, J. H. (1979). Meta-cognition and cognitive monitoring: A new area of cognitive developmental inquiry. American Psychologist, 34, 906-911. http://dx.doi.org/10.1037/0003-066X.34.10.906

Florida Online Reading Professional Development. (2005a). Reciprocal teaching. for-PD's reading strategy of the Month, July 2005. Retrieved from http://forpd.ucf.edu/strategies/ stratreciprocalteaching3.html.

Florida Online Reading Professional Development. (2005b). Reciprocal teaching. FOR-PD's Reading Strategy of the Month, May 2005. Retrieved from http:/forpd.ucf.edu/strategies/ stratreciprocalteaching1.html.

Foster, E., \& Rotoloni, R. (2005). Reciprocal teaching. College of Education, University of Georgia, Athens, GA. Retrieved from http://www.coe.uga.edu/epltt/reciprocalteaching.htm.

Goodman, K. (1967). Reading: A psycholinguistic guessing game. Journal of the Reading Specialist, 6(1), 126-135. http://dx.doi.org/10.1080/19388076709556976

Gough, P. B. (1972). One second of reading. In J. F. Kavanaugh \& I.C. Maltingly (Eds.), Language by ear and eye (pp. 331-358). Cambridge, MA: MIT Press.

Grabe, W. (1991). Current developments in second language reading research. TESOL Quarterly, 25(3), 375-406. http://dx.doi.org/10.2307/3586977

Grabe, W. (2004). Research on teaching reading. Annual Review of applied Linguistics, 24, 44-69. http://dx.doi.org/10.1017/S0267190504000030 


\section{Macrothink}

Journal of Studies in Education

ISSN 2162-6952

2012, Vol. 2, No. 4

Grabe, W., \& Stoller, F. L. (2002). Teaching and researching reading. Harlow: Pearson Education.

Greenfield, P. M. (1984). A theory of the teacher in the learning activities of every life. In B. Rogff \& J. Lave (Eds.), Every day cognition: Its development in social context (pp. 117-138). Cambridge, MA: Harvard University Press.

Greenway, C. (2002). The process, pitfalls and benefits of implementing a reciprocal teaching intervention to improve reading comprehension of a group of year 6 pupils. Educational Psychology in Practice, 18(2), 113-138. http://dx.doi.org/10.1080/02667360220144557

Guthrie, J. T., \& Wigfield, A. (2000). Engagement and motivation in reading. In M.L. Kamil, P. B. Mosenthal, P. D. Pearson, and R. Barr (eds.), Handbook of Reading Research. (Vol. III, pp. 403-22). Mahwah, NJ: Lawrence Earlbaum Associates.

Hacker, D., \& Tenent, A. (2002). Implementing reciprocal teaching in the classroom: overcoming obstacles and making modifications. Journal of Educational Psychology, 94(4), 699-718. http://dx.doi.org/10.1037/0022-0663.94.4.699

Hafiz, F. M., \& Tudor, Ian. (1989). Extensive reading and the development of language skills. ELT Journal, 43(1), 4-13. http://dx.doi.org/10.1093/elt/43.1.4

Harmer, J. (2007). How to teach English. Essex, England: Pearson Education Limited.

Hasan, B. (1994). The effects of the reciprocal teaching of comprehension strategies on the reading abilities of EFL students at Kuwait University. Unpublished doctoral dissertation. University of Colorado.

Hashey, J.M., \& Connors, D. J. (2003). Learn from our journey: Reciprocal teaching Action research. The Reading Teacher, 57(3), 224-235.

Hayashi, K. (1999). Reading strategies and extensive reading in EFL classes. RELC Journal, 30(2). http://dx.doi.org/10.1177/003368829903000207

Hedge, Tricia. (2003). Teaching \& learning in the language classroom. UK: OUP.

Hodge, E., Palmer, B., \& Scott, D. (1992). Meta-cognitive training in cooperative groups on the reading comprehension and vocabulary of at-risk college students. College Student Journal, 26, 440-448.

Janzen, J., \& Stoller, F. L. (1998). Integrating strategic reading in L2 instruction. Reading in a Foreign Language, 12(1), 251-268.

Klingner, J., \& Vaughn, S. (1996). Reciprocal teaching of reading comprehension strategies for students with learning disabilities who use English as a second language. Elementary School Journal, 96(3), 275-293. http://dx.doi.org/10.1086/461828

Koda, K. (2004). Insights into second language reading: A cross-linguistic approach. Cambridge: Cambridge University Press. 


\section{Macrothink}

Journal of Studies in Education

ISSN 2162-6952

2012, Vol. 2, No. 4

Lederer, J. (2000). Reciprocal teaching of social studies in inclusive elementary Classrooms. $\begin{array}{llll}\text { Journal of Learning } & \text { Disabilities, }\end{array}$ http://dx.doi.org/10.1177/002221940003300112

Livingston, J. A. (1997). Meta-cognition: an overview. Retrieved September 23, 2009, from http://gse.buffalo.edu/fas/shuell/CEP564/Metacog.htm

Lysynchuck, L., Pressley, M., \& Vye, N. (1990). Reciprocal teaching improves standardized reading comprehension performance in poor comprehenders. Elementary School Journal, 90(5), 469-484. http://dx.doi.org/10.1086/461627

Maleki, A., \& Zangani, E. (2007). A survey on the relationship between English language proficiency and the academic achievement of Iranian EFL students. Asian EFL Journal, 9, 86-96.

Martin Chang, S. Y., \& Gould, O. N. (2008). Revisiting print exposure: Exploring differential links to vocabulary, comprehension and reading rate. Journal of Research in Reading, 31, 273-284. http://dx.doi.org/10.1111/j.1467-9817.2008.00371.x

Marzano, R. (2001). Classroom instruction that works: research-based strategies for increasing student achievement. Alexandria, VA, USA: Association for Supervision \& Curriculum Development. P 42-43

McLaughlin, M., \& Allen, M. B. (2002). Guided comprehension: A teaching model for grades 3-8. newark, DE: International Reading Association.

Meyer, B. J., Young, C. J., \& Barlett, B. J. (1989). Memory improved reading and memory enhancement across the life span through strategic text structures. Hillsdale, NJ: Erlbaum.

Munby, J. (1978). Communication syllabus design. Cambridge: Cambridge University Press.

Oczkus, L. (2003). Reciprocal teaching at work: strategies for improving reading comprehension. Newark, DE: International Reading Association

Oczkus, L. (2004). Reciprocal teaching at work: Strategies for improving reading comprehension. Newark: International Reading Association.

Palincsar, A. S., \& Brown, A. L. (1984). Reciprocal teaching of comprehension-fostering and comprehension-monitoring activities. Cognition and Instruction, 1(2), 117-175. http://dx.doi.org/10.1207/s1532690xci0102_1

Palincsar, A. S., \& Brown, A. L. (1985). Reciprocal teaching: Activities to promote "reading with your mind.” In T.L. Harris \& E.J. Cooper (Eds.). Reading, thinking, and concept development (pp.147-159). New York: The College Board.

Palinscar, A., \& Brown, A. (1989). Using reciprocal teaching in the classroom: aguide for teachers. Unpublished manual.

Palinscar, A., \& Klenk, L. (1992). Fostering literacy learning in supportive contexts. Journal of Learning Disabilities, 25(4), 211-225. http://dx.doi.org/10.1177/002221949202500402 


\section{Macrothink}

Journal of Studies in Education

ISSN 2162-6952

2012, Vol. 2, No. 4

Palinscar, A., Brown, A., \& Martin, S. (1987). Peer interaction in reading comprehension instruction. Educational Psychologist, 22(3/4), 231-254.

Palinscar, A., David, Y., \& Brown, A. (1989). Using reciprocal teaching in the classroom: aguide for teachers. Unpublished manual.

Paris, S. G., Lipson, M. Y., \& Wixson, K. K. (1983). Becoming a strategic reader. Contemporary Educational Psychology, 293-316. http://dx.doi.org/10.1016/0361-476X(83)90018-8

Pearson, P. D., \& Dole, J. A. (1987). Explicit comprehension instruction: A review of research and a new conceptualization of instruction. The Elementary School Journal, 88(2), 151-165. http://dx.doi.org/10.1086/461530

Pearson, P. D., Roehler, L. R., Dole, J. A., \& Duffy, G. G. (1992). Developing expertise in reading comprehension. In S.J. Samuels \& A.E. Farstrup (Eds.), What Research Has to Say About Reading Instruction (2nd ed., pp. 145-199). Newark, DE: International Reading Association.

Pressley, M. (2002). Comprehension strategies instruction: A turn-of-the-century status report. In C. C. Block \& M. Pressley (Eds.), Comprehension instruction: Research-based best practices (pp. 11-27). New York: The Guilford Press.

Pressley, M. (2006). Reading instruction that works: The case for balanced teaching (3rd ed.). New York: The Guilford Press.

Pressley, M. Woloshyn, V., Lysynchuk, L., Martin, V., Wood, E., \& Willoughby, T. (1990). A primer of research on cognitive strategy instruction: The important issues and how to address them. Educational Psychology Review, 2, 1-58. http://dx.doi.org/10.1007/BF01323528

Promising Practices Network. (2005). Reciprocal teaching. Retrieved from http://www.promisingpractices.net/program.asp?programid=144.

Rahmani, M., \& Sadeghi, K. (2011). Effects of note-taking training on reading comprehension and recall. Reading, 11(2), 116-128.

Reid, R., \& Lienemann, T. O. (2006). Strategy instruction for students with learning disabilities. Guilford Press: New York.

Richards, J. C., \& Rodgers, T. S. (2003). Approaches and methods in language teaching. Cambridge: Cambridge University Press.

Roehler, L. R, \& Duffy, G. G. (1984). Direct explanation of comprehension process. In G. G. Duffy, L. R. Roehler \& J. Mason (Eds.), Comprehension instruction: Perspectives and suggestions (pp. 265-280). New York: Longman.

Rogoff, B., \& Gardner, W. P. (1984). Adult guidance of cognitive development. In B. Rogeff, \& J. Lave (Eds.). Everyday cognition: Its development in social context (pp. 134-157). NY: Cambridge University Press. 
Rosenblatt, L. (1978). The reader, the text and the poem. Carbondale: Southern Illinois University Press.

Rosenshine, B., \& Meister, C. (1994). Reciprocal teaching: A review of the research. Review of Educational Research, 64(4), 479-530.

Rumelhart, D. E. (1977). Toward an interactive model of reading. In Dornic, S. (Ed.), Attention and Performance, V.1, 573-603. New York. Academic Press.

Smith, F. (2004). Understanding reading (6th ed.). Mahwah, NJ: Lawrence Erlbaum. standardized reading comprehension performance in poor comprehenders. Elementary School Journal, 90 (5), 469-484.

Stanovich, K. E. (1980). Toward an interactive- compensatory model of individual differences in the development of reading fluency. Reading Research Quarterly, 16. 32-71. http://dx.doi.org/10.2307/747348

Stricklin, K. (2011). Hands-on reciprocal teaching: A comprehension technique. The Reading Teacher, 64(8). http://dx.doi.org/10.1598/RT.64.8.8

Taylor, B., \& Frye, B. (1992). Comprehension strategy instruction in the intermediate grades. Reading Research and Instruction, 32(1), 39-48. http://dx.doi.org/10.1080/19388079209558104

Todd, R., \& Tracey, D. (2006). Reciprocal teaching and comprehension: A single subject research study. ERIC document reproduction service No. ED 491502.

Tolstefl, J. (2007). Miscue analysis in reading a second language. Cambridge University Press.

VanDen B. P., \& Kremer, K. E. (2000). The mind in action: What it means to comprehend during reading. In B. M. Taylor, M. F. Graves, \& P. VanDen Broek (Eds.), Reading for meaning: Fostering comprehension in the middle grades (pp. 1-31). New York: Teachers College Press.

VanDuzer, C. (1999). Reading and the adult English language learner. ERIC Digest. ED433729.

Vygotsky, L. S. (1978). Mind in society: The development of higher psychological processes. Cambridge, MA: Harvard University Press.

Wilson, J. (1988). Implications of learning strategy research and training: What is has to say to the practitioner. In C. Weinstein, E. Goetz, \& P. Alexander (Eds.), Learning and study strategies: Issues in assessment, instruction, and evaluation (pp. 323-331). San Diego, CA: Academic Press.

Yang, Y. (2000). Diagnosis and remediation on TVES college students' English reading comprehension difficulties. Taipei: The Crane Publishing Co.

You, Y. L. (2004). Curriculum and Research Development Center for Commerce Education. Retrieved January 26. 